\title{
THE EFFECT OF SOCIO-DEMOGRAPHIC AND OBSTETRIC FACTORS ON EARLY INITIATION OF BREASTFEEDING IN TEGAL DISTRICT, CENTRAL JAVA
}

\author{
Juhrotun Nisa ${ }^{1,2)}$, Harsono Salimo3), Uki Retno Budihastuti4) \\ 1)Diploma Program in Midwifery Harapan Bersama, Polytechnics, Tegal \\ 2)Masters Program in Public Health, Sebelas Maret University \\ 3)Department of Pediatrics, Dr. Moewardi Hospital, Surakarta \\ 4)Department of Obstetric and Gynecology, Dr. Moewardi Hospital, Surakarta
}

\begin{abstract}
Background: It is estimated that approximately 10 million children die every year worldwide. Forty five percent of those deaths are caused by malnutrition either directly or indirectly. Studies have shown that breastfeeding in the first hour can reduce neonatal death to $22 \%$. However, breastfeeding practice in the first hour of life reaches only $43 \%$ of the newborns in the world. In South Asia, early initiation of breastfeeding is only $41 \%$ of the newborn, while in Indonesia it is only $34.5 \%$. This study aimed to determine the effect of socio-demographic and obstetric factors on early initiation of breastfeeding in Tegal District, Central Java.

Subjects and Method: This was an analytic observational study with crosssectional design. This study was conducted at 4 Community Health Centers (Puskesmas Pagiyanten, Puskesmas Pagerbarang, Puskesmas Bumijawa, Puskesmas Jatinegara) and Dr. Soeselo hospital, Tegal District, Central Java, from February to March 2017. A sample of 121 post partum mothers were selected for this study by exhaustive sampling. The dependent variable was time from birth delivery to breastfeeding. The independent variables were maternal education, maternal employment status, maternal knowledge, family income, parity, antenatal care (ANC) visit, and health provider support. The data were collected by questionnaire and were analyzed by multiple logistic regression.

Results: Early initiation of breastfeeding was positively affected by maternal education $\geq$ High School $(\mathrm{OR}=3.90 ; 95 \% \mathrm{CI}=1.14$ to $13.37 ; \mathrm{p}=0.030)$, maternal work outside the house $(\mathrm{OR}=7.93 ; 95 \% \mathrm{CI}=1.68$ to $37.52 ; \mathrm{p}=$ 0.009), $\mathrm{ANC} \geq 4$ times $(\mathrm{OR}=3.48 ; 95 \% \mathrm{CI}=0.82$ to $14.81 ; \mathrm{p}=0.092)$, and strong health provider support $(\mathrm{OR}=12.58 ; 95 \% \mathrm{CI}=4.30$ to $36.77 ; \mathrm{p}<0.001)$

Conclusion: Early initiation of breastfeeding is positively affected by maternal education $\geq$ High School, maternal work outside the house, ANC $\geq 4$ times, and strong health provider support.
\end{abstract}

Keywords: Socio demographic, obstetric factor, early initiation breastfeeding

Correspondence: Juhrotun Nisa. Masters Program in Public Health, Sebelas Maret University, Jl. Ir. Sutami 36 A, Surakarta 57126, Central Java, Indonesia. Email: nisa.jn20@gmail.com. Mobile: +6285642905995. 